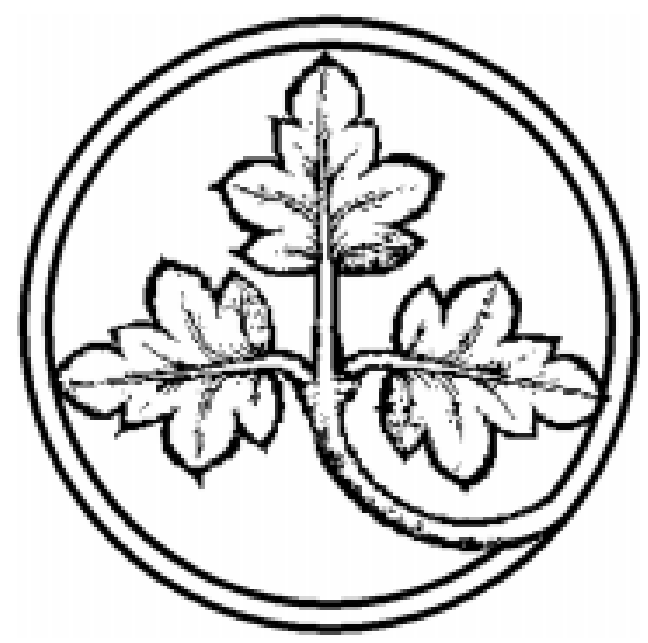

Gemeinschaftsgüter: Recht, Politik und Ökonomie

\author{
Preprints \\ aus der Max-Planck-Projektgruppe \\ Recht der Gemeinschaftsgüter \\ Bonn \\ 2002/14
}

Interorganizational Cooperation and

Intraorganizational Power:

Early agreements under codecision and their impact on the Parliament and the Council

\author{
von \\ Henry Farrell / \\ Adrienne Héritier
}




\title{
Interorganizational Cooperation and Intraorganizational Power: Early agreements under codecision and their impact on the Parliament and the Council
}

\author{
Henry Farrell and Adrienne Héritier*
}

\begin{abstract}
Current research on the main bodies of the European Union (Council, Commission, Parliament) tends to concentrate either on relations within these bodies, or on relations between them. The result is that little attention is paid to how these two intersect; that is, to how changes in relations between bodies can affect relations among them, and vice versa. In this article, we examine the effects of the introduction of the codecision procedure on relations between the Council and the Parliament. We show that the changes in informal and formal relations between Council and Parliament associated with codecision have affected power relations within Council and Parliament in important ways. In a second stage of development, actors who have been disadvantaged by these changes have sought to redefine relations yet again in order to restore their power over legislative outcomes.
\end{abstract}

* We are grateful to Christoph Engel and Henri Tjiong for their critical and helpful comments. 


\section{Introduction}

Legislating in the European Union is a notoriously complex process. It not only involves bargaining between the main actors - Parliament, Council and Commission ${ }^{1}$ - but also bargaining "within" each of them, as each collective actor decides its position through internal negotiations among its constituents. Increasingly, these two decision spaces of the Parliament and the Council have come to intersect, as new legislative procedures have led to new forms of interdependence between them. However, the consequences of this intersection are at best imperfectly captured by the existing literature. Most current work focuses either on decision-making within Parliament or Council (Lewis 2000), paying little attention to relations between them, or else purely on relations between Parliament and Council, treating internal decision-making processes as exogenous, or as at most a constraining factor (Crombez 1997; Hix 2002; Garrett and Tsebelis 2000; Farrell and Héritier forthcoming). Thus, there is a dearth of ways to conceptualize how relations between these bodies affect relations within them, and vice versa.

The new forms of interaction that have sprung up around the codecision process and early agreement procedure with their innumerable "informal trialogues" present an important case for understanding how interactions between Council and Parliament (Stacey 2001), and within Council and Parliament, intersect. Codecision has had important and unpredicted consequences for the balance of power between the two bodies (Farrell and Héritier forthcoming). Yet, the possibility of new forms of contact between the bodies has had significant implications for interactions within the bodies and their balance of power. They have had the initial effect of increasing the power of some actors within each body over legislative outcomes, and decreasing the power of others. Those who have lost power have sought to respond; but have done so in different ways. The Council has strengthened and centralized its internal monitoring and informational mechanisms, while seeking to reshape Council-Parliament relations on the basis of a more structured relationship between the Council and the larger groups within Parliament. Concerned actors in the Parliament, in contrast, have found it difficult to create collectively binding rules. Like the Council, they have pressed for more structured relations between the two bodies - but on the basis of the pre-existing Parliamentary committee system.

How have codecision and early agreements, and the forms of interaction surrounding them, affected relations among actors within Council and Parliament? Why do intraorganizational outcomes differ across Council and Parliament as they seek to respond to similar interorganizational pressures and why do these bodies differ in their views of a necessary redefinition of interinstitutional relations? In this article, we provide an account of how the specific form of the relationship between arenas may affect the relative power of individual actors within them. We further go on to examine how those actors who are disadvantaged by increasing levels of interdependence may seek to redefine terms to their advantage by reshaping the relationship between arenas. We derive hypotheses from our arguments, and apply them to Council-Parliament relations under the codecision procedure, and especially under the early-agreement provisions introduced in

1 We will address the role of the Commission in forthcoming work. 
the Amsterdam Treaty. We explore whether these relationships - and how they have changed over time - with their repercussions within the Parliament and the Council provide support for our hypotheses.

\section{Informal cooperation in interlinked legislative arenas}

The introduction of the legislative procedure of codecision, and its early agreement provisions in particular, has led to the interlocking of two decision-making arenas, those of the Council and the Parliament respectively. The first arena is that of decision-making within the Council itself. The Council seeks to reach a common position on specific items of legislation, under the shadow of a particular voting rule (unanimity or qualified majority). ${ }^{2}$ While member states seek to reach consensus if possible, and to avoid formal votes, they nonetheless remain highly aware of their bargaining strength under the relevant voting procedure. The Council has a Presidency, which rotates among the member states every six months. The Presidency has important agenda-setting powers in pushing specific items of legislation, but is primus inter pares, rather than a hierarchical superior in any strong sense. The Committee of Permanent Representatives (COREPER), which consists of career civil servants and diplomats from the member states, plays a key role in preparing the Council's response to legislation; political disagreements that cannot be resolved at this technical level are passed to government ministers, who meet in the form of the Council at regular intervals, and, if necessary, up to the European Council of heads of state and foreign ministers (Wallace forthcoming).

The second arena is that of decision-making within the Parliament (Lord 1999; Shackleton 2000; Corbett, 2000). Here, the process of legislation is rather less centralized than in the Council. Parliament has a number of committees, which play a vital role in preparing and discussing legislation. A rapporteur and shadow rapporteurs are appointed for each item of legislation, who then seek to shepherd it through amendments, and create the basis for consensus within the committees. After discussion and voting in committee, legislation is then voted on by the entire Parliament in plenary; typically, although not universally, plenary follows the substantive position of the committee in question. The Parliament's secretariat plays a role, too; it seeks to support the legislative process more generally, and to provide some coherence to it. However, individual committees have their own staff and institutions and are highly jealous of their prerogatives. Under this system, discussion within committee has typically been of considerable importance, and committee chairmen have traditionally had considerable power and independence in setting the legislative agenda.

These two arenas have been brought into much closer contact by the creation and extension of the codecision procedure. Codecision, in the wake of the Amsterdam Treaty, applies to 38 articles of the Treaty. Under codecision, the European Parliament delivers its opinion on the Com-

2 We note that different voting procedures may intersect with the factors we identify in an interesting fashion. However, detailed discussion of this intersection is beyond the remit of this article. 
mission's proposal before the Council adopts its common position. The Council then adopts its position (which may reflect certain of the Parliament's proposals) and the Parliament may then, in a second reading, make amendments to the Council's position. If the Council does not accept all of Parliament's amendments, a conciliation committee, consisting of representatives from both Council and Parliament is convened, which has six weeks to draw up a joint text. If this text is not accepted by both Council and Parliament, it fails; a procedure under the Maastricht Treaty whereby the Council could then reintroduce the text of the common position was removed in the Amsterdam Treaty.

Codecision means that Council and Parliament interact on the basis of a plethora of formal and informal relations. The key actor on the Council's side is the member state holding the Presidency. Each Presidency sets out a legislative agenda which it seeks to carry through during its six months in office. The Presidency represents the position of the Council as a whole, but has some leeway in so doing. On the Parliament's side, the key actors are more various; they include the rapporteur for the specific legislative item, the committee chair, the shadow rapporteur and coordinator for the relevant committees, one of the four Vice-Presidents of the Parliament and MEPs with expertise in the issue area at stake.

Legislative cooperation was substantially enhanced for certain dossiers in the Amsterdam Treaty. A new fast-track procedure was introduced for particular items of legislation, whereby the Parliament and Council sought to reach common agreement before Council had adopted a common position, or indeed Parliament had issued a formal opinion. The Parliament takes a position first, after which the Council adopts a Common Position. Originally, it was intended that this procedure would apply to technical and politically uncontroversial dossiers in which substantial disagreement between the two bodies was unlikely. However, it has been increasingly extended to more politicized issue areas, where there is a formal deadline for legislation, or some other need for urgent action. The Lisbon conclusions, for example, laid down strict deadlines for action in a number of areas related to information technology and e-commerce; this necessitated the use of the fast-track procedure in legislative initiatives such as the regulation unbundling the local loop, and the e-commerce directive.

The codecision procedure, after a stormy beginning, led to the creation of new modes of informal contact and communication between Council and Parliament. Initially, there was little discussion between the two sides. After a period of institutional bargaining (Farrell and Héritier forthcoming), "trialogues" - meetings between Council, Parliament and Commission - were instituted in order to provide a means whereby the respective bodies could hammer out compromises informally, between the second reading and the Conciliation Committee, in a less formalized setting than the Committee itself. These trialogues involve on the Council side the President of COREPER and the chairman of the relevant working group, and on the Parliament's side, the rapporteur, the committee chairman, one of the Vice-Presidents of the Parliament, and in some cases the shadow rapporteurs or coordinators from the various political groups. 
Gradually, more informal trialogues were held already during first reading. (Farrell and Héritier, forthcoming) They may be seen as the capstone of a more general process of informal interorganizational discussion and debate. As one Council staff member describes it: "Confidence building started with the informal trialogues. They make it possible to speak more frankly and to explain what the underlying reasons are. You also can say: here is a real problem - we cannot go any further on this, please recognize this, but we will yield in another issue, this 'give and take' becomes possible" (Interview Council Secretariat Oct. 2001). Typically, an informal trilateral meeting is held soon after the Parliament and Council have individually gone through a Commission proposal. This meeting may be followed by others, in which the two sides report back in broad terms about the progress of discussions within Council and Parliament, and seek both to reach agreement where possible, and to identify possible areas of contention. As the vote in the relevant parliamentary committee approaches, the two sides begin to exchange compromise texts, and then arrange a trialogue proper when there is a clear possibility of agreement being reached. "Apart from a few extremely formal encounters, we have reached the point of almost weekly informal meetings." (EP Activities Report, May 1999:7/8).

Over time, informal dialogue, or "pre-conciliation" has become prevalent for dossiers, especially those where success or failure may have serious political consequences. The process of coming to an early agreement involves careful negotiations between the relevant mediating or negotiating agents, who inform each other about how the discussion is progressing in their respective institutions, and discuss possible amendments. These, in turn have to be discussed with key figures in the mediating agents' own institutions. This requires a feeling both for the sensitivities of the other institution and the sensitivities of actors in one's own institution in negotiating its own position: Thus a Presidency of Council member points out that "il ne fallait surtout pas en sortant du Conseil qu'on arrive avec un texte figé, qu'on ne puisse pas prendre à bord les amendements du Parlement. En même temps il fallait avoir un texte suffisamment consolidé pour unir les étatsmembres." (Interv. Perm. Repr. B, Jan. 2002). Further, MEPs must be able to express their ideas regarding amendments during first reading "d'une manière visible" to their voters (Interv. Perm. Repr. B, Jan. 2002).

Informal discussions do not only take place in trilateral settings. The Council Presidency, has begun more and more to engage directly with powerful figures within the Parliament on a bilateral level, to ensure that agreements will stick. Parliament comprises a variety of groups, whose willingness to agree in plenary to concessions accepted by trialogue negotiators, or even the relevant committees, cannot always be taken for granted. This has been especially problematic in situations where the chairman of a committee and the rapporteur represent smaller parties within the Parliament; they might not be able to muster the necessary votes to ensure that a compromise is passed, so that an agreement they have reached is later disowned by the Parliament as a

3 "We had to be careful not to come out of Council debates with a fixed text which did not allow [us] to take the amendments of Parliament into account. At the same time we needed a text which is sufficiently consolidated to create a consensus among member states." (own translation) 
whole. ${ }^{4}$ Thus, it is necessary for figures on the Council to create relationships with key figures in the Parliament, especially within the two largest parties, the Christian Democrats and the Social Democrats, so as to ensure that there is sufficient support for items of legislation.

As described by one COREPER functionary who was responsible for shepherding a particular item of legislation through: "Il faut aussi intégrer les personnalités très fortes dans le Parlement qui s'occupent de la [area of activity in question] et ont une forte stature. Et à la fin il faut forcément qu'il y ait un amendement qui vient d'eux. Donc il faut en trouver un qui soit assez symbolique"5 (Interv. Perm Repr. B, Jan. 2002). The Council Secretariat, which has a permanent role in the legislative process, has sought to cultivate such relationships. However, it is only the current Council Presidency, which leads negotiations and can make lasting political bargains. Ministers in member state governments now deliberately seek to foster relationships with key figures in the Parliament, in contrast to the past, where they sought to avoid dealings with Parliament as much as possible. "The development of relationships has advanced dramatically, and those relationships are now not just at senior official level, but at ministerial level, with key members of Parliament. That's happening at least nine months in advance [of the country taking up the Presidency]"(Interv. Council Secr., Oct. 2001).

Thus, the creation of the fast-track procedure, in which Parliament and Council seek to reach agreement very early in the negotiation process, has led to a further proliferation of contacts between the two (Stacey 2001). These contacts may affect the final outcome more directly than the 'traditional' procedure. Council and Parliament do not confront each on the basis of pre-agreed positions; "it is another ball game...You don't have any decision taken beforehand on the Council side, and no amendments adopted in the Parliament." (Interv. COREPER, Oct. 2001). Rather, they engage with each other before either has reached a formal position.(Interv. COREPER, Oct. 2001). In consequence, it is much easier for Parliament to influence deliberations within the Council, and vice versa. "Since the new procedure..., since we have this possibility to come to agreement on the first reading...the Council is respecting this very thoroughly. We are looking from the very beginning at what Parliament thinks, and we try to incorporate this. And we are delaying political agreements if Parliament is not ready." (Interv. Council Secretariat, October 2001).

4 While there appear to be informal norms militating against such outcomes, they are not observed under every circumstance.

5 "You also have to incorporate the strong personalities in the Parliament, who are experts in the policy area under discussion and hold a strong position. At the end there has to be an amendment which comes from them. And you have to find one which has strong symbolic character". (own translation)

6 "It used to be the case in former times, that we practically always had our common position ready when Parliament finished its first reading, and it was politically too complicated to change this with an almost existing political agreement. So nothing of the Parliament's amendments was taken on board. And then Parliament reconfirmed most of the amendments in second reading, and we had most of the amendments in conciliation. So this was the usual, this comes from the old times when Council could always overrule Parliament." (Interv. With Council Secr. Oct. 2001) 


\section{Interorganizational bargaining and its intraorganizational impact: Theoretical explanation and hypotheses}

What are the intraorganizational impacts of the on-going informal interorganizational negotiations between the Council and EP? While much research has been done into policy making across multiple arenas in the last fifteen years, surprisingly little attention has been paid to the effects of multiple arenas on actors' bargaining power within one arena. The literatures on "multi-level governance" (Marks, Hooghe and Blank, 1996; Hooghe and Marks 2001), on veto players and on nested games (Tsebelis 1990) and "two level games" (Putnam 1988, Evans, Jacobson and Putnam eds. 1993, Milner 1997), all provide and important insights, but for different reasons fail to provide insights into institutional change, which is either held constant or unexplored. While principal-agent theory (Pollack 1997, Majone 2001) provides arguments as to what institutions are likely to arise in principal-agent relationships, it assumes a simple relationship of delegation, and tends to be uninterested in the internal effects of these institutions.

In this article, we seek to examine how it is that the relationship between different arenas (the EP and the Council) may translate into power differentials between actors within each arena and between the two arenas, affecting bargaining, and, consequently, institutional evolution. Our previous work (Farrell 2002, Héritier 2001, Héritier 2002), demonstrates how multiple arenas of policy making may indeed affect the power of actors to shape institutional alternatives, but does not focus on the specific mechanisms involved and their impact within one arena/organization. In this article, we seek to provide an explicit theory, adapting an approach first set out in Farrell and Héritier (forthcoming), which built on work in the historical institutionalist (Pierson 2000) and rational choice institutionalist (Knight 1992) literature. Here, we focus our attention on a lower level of aggregation than in previous work. Our argument proceeds as follows. In a first stage of institutional development, change in the relationship between decision-making bodies will have an impact on the power of individual actors within decision-making bodies to influence legislative outcomes. This change may come to be instantiated in informal rules or understandings (Stacey 2001, Farrell and Knight 2002). In a second stage of institutional development, actors who find themselves weakened under the new set of arrangements will seek to respond through themselves promoting institutional change. This may in turn give rise to further adaptations within institutions, and so on, in an iterated process.

\subsection{Bargaining across arenas - power and the role of mediating actors}

The effects of multiple arenas of decision-making on legislative outcomes may be understood in terms of their effects on the power of individual actors to influence these outcomes. Specifically, we assume both that actors will have a powerful motivation to maximize their decision making competences, and that their ability successfully to realize this aim will depend on their differential bargaining power. We claim that this bargaining power will be affected by their specific po- 
sition within and between the relevant arenas. ${ }^{7}$ In the context of law-making, decision-making competences will primarily concern the shape and detail of legislation that is agreed and passes into law - what we call legislative outcomes. Knight (1992) suggests that power primarily consists in the ability to affect another's choice set. Actors will be more powerful if they can affect the possible set of actions that other actors may choose from. Power in one setting may translate into influence over outcomes in another. As Bowler and D. Farrell (1995) demonstrate, for example, certain actors in the European Parliament, such as rapporteurs and party leaders, exercise significant decision making powers, and may use their influence to gain positions of prominence on more powerful committees. Further, as Knight and others, following Max Weber emphasize, power is a relational concept, rather than an absolute one; it consists in one's ability to constrain others' choices. It follows that power is not simply a matter of formally granted competences; it may also derive for example, from informal influence (informal leadership within a given group), or from expertise (unique knowledge which allows one to frame issues so as to shape the collective action of others; c.f. Fligstein 2001).

There is little discussion in the literature of how the existence of other arenas of interaction may affect actors' power to achieve outcomes within a particular arena, if the two are interdependent. ${ }^{8}$ However, this is an important factor affecting power relations. If actors are able to work in multiple games, they may be able to leverage change in one arena (Arena A) into change in another (Arena B), in a manner that would have been impossible had the arenas not been interdependent. The ability of actors so to do will depend on two sets of factors. First are those that determine the degree and direction of interdependence in the relationship between arenas. Second are those that determine the specific positions of actors within this relationship.

The first condition is the degree and direction of interdependence between the two arenas. Here, interdependence may be defined as the degree to which outcomes in one arena are dependent on outcomes in another. Interdependence under this definition does not imply perfect information flows between the different arenas (as developed below, the converse may be true). Furthermore, interdependence may be asymmetric. Outcomes in Arena A may be far more dependent on outcomes in Arena B than vice versa. If there is only marginal interdependence between the two arenas, then it will be difficult for actors to affect outcomes in one arena by affecting them in the other. Likewise, if Arena B is far more dependent on Arena A than vice-versa, then it will be difficult for actors to influence outcomes in Arena A by influencing them in Arena B, although they may be able easily to influence outcomes in Arena B by influencing outcomes in Arena A. The degree and direction of interdependence between two arenas will not only be a function of the formal relationship between them, but also of informal rules governing relations which in turn are determined by the time constraints to which the interacting arenas are subject, their vul-

7 This argument is congruent with the theory of organizational sociology of Crozier and Friedberg on the power of those actors within an organization that control the borders of an organization (Crozier and Friedberg 1977)

8 The most comprehensive attempt in the literature to come to grips with this is Tsebelis (1990), which, however, assumes a static perspective for theoretical reasons. 
nerability towards failure of negotiations and their relative resources (Farrell and Héritier forthcoming).

The second set of conditions involves the specific position of actors within the overall relationship of interdependence between arenas. Here, the crucial variables are the degree to which an actor has formal and informal negotiating authority vis-à-vis the other body. This position is strongly linked to the degree to which actors may informally control information flows between arenas.

Negotiating authority may be granted formally; some actors may be explicitly delegated the power to represent a collective body in negotiations. However, it may also be substantially conditioned by informal power based on a particular networking capacity, political support or policy expertise which an actor enjoys within her own organization and which in turn is needed to represent a position forcefully vis à vis the other arena. Additionally, negotiation between arenas may allow actors with negotiation authority in one arena some scope to influence or even shape debate in the other, and thus increase the ability of these actors to shape final legislative outcomes in an indirect fashion.

Having formal or informal negotiation authority may allow control over information which has important effects on legislative outcomes. Actors' beliefs regarding what is transpiring in the other arena will have consequences for their perceived feasible sets; actors will update their beliefs about what actions are possible or impossible, beneficial or harmful, according to their beliefs regarding what is happening in the other arena. To the extent that certain actors have privileged access to information about another arena because of their formal or informal role in negotiation, they will have a more precise understanding of what is possible and impossible in that other arena, and therefore of which strategies are most appropriate. They may disburse this information strategically, perhaps even misrepresenting likely outcomes in Arena B in order to influence actors in Arena A. Thus, not only negotiating authority as such, but control over information flows between arenas may increase the power of certain actors to shape legislative outcomes. But the second is mostly linked to the first.

Thus, in the first stage of iteration, a change in the degree of interdependence will have important effects on the relative power positions of actors within the relevant arenas. Ceteris paribus, actors who have access to the other arena through their formal or informal negotiating authority based on networking capacity, political support and policy expertise will have effect of having some control over information flows between arenas, will have increased power to determine legislative outcomes as interdependence increases. Correspondingly, other actors without such privileged positions may find that their relative power diminishes.

However, in a second stage of iteration, the actors whose relative power has diminished may respond, by seeking to restrain those actors who do have such access to interorganizational bargaining. Under certain circumstances they may be successful in so doing. An increase in power over legislative outcomes does not necessarily translate into control over the internal and inter- 
body procedures under which legislation is produced (although such control is likely to be fungible in part). Thus, we may expect that those actors who (a) find their power over legislative outcomes diminished, and (b) retain some power over procedure, will seek to use this to claw back some power over legislative outcomes. They may do so in three ways. First, they may seek to redefine the scope and nature of interdependence between arenas in a manner that either limits interdependence, or redefines it in such a way as to privilege their own particular intraorganizational position. Second, they may seek to redefine the direction of interdependence, so that their own arena of decision making becomes more important vis-à-vis the other, making it more difficult for other actors to use the external arena as a source of leverage. Third, they may seek to redefine internal procedures within their own arena so as to limit the effective negotiating authority or control over information of the other actors.

In this second stage, the willingness and ability of actors to redefine interactions, and to claw back control over legislative outcomes that they have lost in the first, depends on the specific power constellation among actors. One may imagine circumstances in which it is relatively easy for all actors to agree on institutional changes that restrain actors from taking advantage of their negotiating authority or control over information. If such advantages are relatively evenly distributed - or are temporary, and rotate among actors in a fairly unbiased fashion - then actors who possess these advantages will be far less inclined to invest resources in defending them; they may be said to be cross-cutting (Sugden 1986). Indeed, where such privileges rotate, all actors will have good reason to agree to a set of common restraints with other actors so as to make sure that actors which temporarily enjoy a privileged position will be restrained from abusing it. However, in circumstances where privileges are not evenly spread, and do not rotate, one may expect that those actors who have such privileges will defend them. Under these circumstances, reform will be more difficult and contested, and will depend on power relations, and specifically on actors' relative power over the procedures under which legislative outcomes are reached, rather than the legislative outcomes themselves.

From the above discussion, we can draw the following hypotheses about the effects of interdependence between arenas on bargaining power, and hence on legislative outcomes.

In the first stage:

(1) When interdependence between arena $A$ and $B$ increases, then, ceteris paribus, there will be an increase in the power of actors with formal negotiating authority between arenas to affect legislative outcomes.

1.1 Actors with informal intraorganizational power based on networking capacity (e.g. based on policy expertise) and ability to mobilize others will have increased power to determine legislative outcomes, given the new possibilities of interorganizational bargaining.

1.2 Correspondingly, other actors without such authority will lose power in relative terms; 
(2) when interdependence between arena $A$ and $B$ increases, then, ceteris paribus, actors in one arena with privileged access to information about deliberation in another, and the ability selectively to provide that information to others, will have increased power to affect legislative outcomes.

And regarding the direction of interdependence and resulting power of mediating agents we propose that

(3) the more arena $A$ depends on arena $B$, the more actors in arena $A$ can influence outcomes in arena $B$, and the less agents from arena A can influence outcomes in Arena $B .{ }^{9}$

In the second stage:

(4) actors which lose power through an increase in interdependence will seek to regain it through institutional change in a second phase of institutional development. This institutional change may involve efforts

- to redefine the terms and direction of interdependence,

- or the access of actors to negotiating authority and/or privileged information under interdependence.

(5) Where negotiating authority is evenly spread, or is rotated, it will be relatively easy for actors to agree institutional solutions in a non-conflictual manner. Where negotiating authority is unevenly distributed, and is not rotated, institutional change will be conflictual and difficult to bring through.

In the following section we explore these hypotheses on the basis of empirical information gathered through an extensive analysis of documents, and 24 interviews with actors in the European Parliament, the Council and the Commission in 2001 and 2002.

\section{2 Hypotheses in the light of the empirical data}

\subsubsection{The intraorganizational consequences of interorganizational cooperation}

Our first hypothesis claims that

When interdependence between arena $A$ and $B$ increases, then, ceteris paribus, there will be an increase in the power of actors with formal or informal negotiating authority between arenas to affect legislative outcomes. Correspondingly, other actors without such authority will lose power in relative terms.

9 This is so obvious a point as to very nearly be a tautology 
To investigate these claims it is necessary to briefly recall again - as mentioned above - the agents who formally or informally negotiate legislation with members of the other body. On the Council's side it is the Presidency. On the Parliament's side, the agents are more various, the rapporteur and the shadow rapporteurs for the specific legislative item and the coordinators for political groups in the relevant parliamentary committees; and one of the four Vice-Presidents of the Parliament. In addition, self-appointed actors without an "official" mandate, but with informal political clout or policy expertise, may play an important role in informal negotiations across bodies.

The empirical findings provide rich evidence that informal practices of agreement allow individual actors within Parliament and Council to further their specific interests in a manner that may upset previously existing balances of power. This is especially clear in the Parliament. Certain actors are privileged by the new forms of informal cooperation. Rapporteurs in particular which play a central role in conventional codecision dossiers, do so even more markedly, in early agreement dossiers. In the latter, they may have quite extraordinary latitude to set the agenda of negotiations. As described by one MEP, who was rapporteur for such a dossier: "I had an enormous free hand in negotiating with the ...presidency and doing so more or less on my own, with assistance from my office and the Committee secretariat, but I basically did it on my own. The shadow rapporteurs didn't take much of an interest. I would then report back to the committee." (Interv. Rapporteur A, Sept. 2001) Or from the viewpoint of the Council: "Le rapporteur a une importance énorme. Il est le point de contact privilégié avec la Présidence." ${ }^{\prime 10}$ (Interv. Perm. Repr., Oct. 2001)

The second group of actors who have come to play a more important role under the new arrangements are the power-brokers within the larger political groups in Parliament, the Christian Democrats and the Socialists. These groups have considerable clout because of their voting strength; thus, figures in the Council are increasingly bypassing the committee structure and going directly to influential figures in these parties. As described by one Council official: "You need to know your Parliament. So when you negotiate an issue, you have to develop contacts with key persons and big groups....The key persons would be the spokespersons of the Socialists and the Christian Democrats. You have got to have them on your side...they are the people with the numbers" (Interv. Council Secretariat A, Oct. 2001). Or as described by an MEP: "Here (in the EP) ...you have to convince one member after the other. There are some barons, some key players, who speak to people. You have to stay in touch with them. It is a kind of a network of people that you have to cooperate with." (Interv. Rapporteur B, Jan. 2002). It is much easier for a parliamentarian to build such a network (and hence enhance her negotiating power) if she is a political group's coordinator in a committee. "If you are only a rapporteur and not a coordinator, it is not so easy" (Interview Rapporteur B, Jan. 2002).

10 "The rapporteur has an enormous importance. He is the privileged contact point of the Presidency" (own translation) 
Further, specialist parliamentarians with negotiating skills win out over generalists. There is a movement away from " 'all the Parliament', or 'all the committee' to some specialists, the rapporteur, the President, the two Vice Presidents. You do have very competent people...very much negotiators...You have all these people in the EP who get professional in negotiation" (Interv. Perm. Repr. Jan.2002). Specialised actors become more and more important because of their ability not only to negotiate, but to mobilize coalitions for agreements reached in negotiation they may act as 'skilled social actors' (Fligstein 2001), framing issues for others so as to create the conditions for collective action.

By the same token the empirical evidence shows that other actors have lost influence under the new arrangements. Most obviously, the smaller political groups in the Parliament find themselves increasingly excluded from decision-making. As a MEP for the Greens pointed out, "as a small group, we would not be as involved as the larger groups [in informal dialogues]...we are not part of that informal consensus." (Interview MEP, Sept. 2001). Not surprisingly they disapprove of early agreements. Even in those instances where a smaller group has a direct say in codecision negotiations, for example because it holds the relevant rapporteur's position, the Council will maintain informal contacts with the larger groups, and call the smaller party's bluff when it feels that this group is overstepping its mark. (Interv. Council Secretariat A, Oct. 2001). Smaller political groups have typically relied on their ability formally to propose amendments in committee as a means of influencing the legislative process. The Green group invariably states its position formally in committee, even if there has been a formal agreement during first reading. (Interv. MEP, Sept. 2001) However, they now find that their amendments are increasingly less likely to get through, because of informal deals reached between the large parties and the Council in order to avoid going to conciliation. They have little resources to prevent this; "if the two large groups, because it does come down to numbers, decide that they don't want to go to conciliation, and therefore they don't table amendments, they can vote anything down anyway because it usually needs a two-thirds majority" (Interv. MEP, Sept. 2001). This leads to “...a constant tension ... between groups, especially small groups and large groups," in which the former feel "that these informal trialogues ... exclude them completely, that they are undemocratic" (Interv. Commission, Sept. 2001)

Actors in the Council, by contrast, approve of more streamlining and concentration of decision making in Parliament. They argue that the first reading cannot be a "playground" anymore for all kinds of actors, in which everyone can make whatever amendments they want. As one member of the Council secretariat pointed out: "In the past we always had a bulk of amendments which were not serious... This you cannot do, if you want to come to conclusion at first reading...This creates some frustration among those who used to do this ." (Interv. Council A, Oct.2001).

At one stage the Council pressed directly for a more direct formal role to be given to the larger parties in Council-Parliament deliberations to recognize this reality. However, the resulting furore in the Parliament led Council to back down on the position. (Interv. Council Secr. B, Oct. 2001). 
The second group of actors which is increasingly losing out in the new forms of informal cooperation comprises more traditionally powerful figures within the Parliament; the committee chairmen. In the past, chairmen have been highly successful in carving out fiefdoms in particular policy areas (Lord 1999), where they are more or less independent from outside supervision. Committee chairmen retain an important part in conventional trialogues. However, they are threatened by early agreement dossiers which they have handled in a quite varied and idiosyncratic fashion. In informal agreements they may play little or no role, and are often effectively presented with a fait accompli by the rapporteur and coordinators for the larger political groups. The result has been considerable disquiet. "The informal negotiations are always done by the rapporteurs and not by the committee chairmen... The influence of the committee chairmen is small. ... They are dependent that the rapporteurs deliver certain results. The role of the rapporteur becomes more and more important and [that of] the shadow rapporteurs." (Interv. Rapporteur B, Jan. 2002).

In the Council as well informal bargaining with the Parliament at first reading has affected internal structures and processes: it has strengthened some actors, and weakened others. Most obviously, the power of the Presidency has been enhanced vis-à-vis other member states. Coming to early agreements at first reading opens new possibilities for the Presidency to have its policy agenda adopted within six months. It can influence much more the progress of a dossier and seek to accelerate proposals that it would like to see enacted during its six months in office (Shackleton 2001:7). Therefore, the Presidencies push for early agreements to conclude their agendas (Interv. Commission, Sept. 2001). While Presidencies previously tried to get as many common positions as possible, now they try get as many early agreements as possible with Parliament (Interv. Perm. Repr., Jan. 2002).

The working style of the Presidency “...has changed fundamentally.” (Interv. Perm. Repr. Jan. 2002) Previously, there was no contact with the EP during the first reading except perhaps at the ministerial or ambassadorial level. The Presidency's job had been to find an agreement between the 15 and the Commission. "But now the Presidency with 'something like a mandate' from the working group negotiates with Parliament...But it (the mandate) is not clear: the Council has not yet clarified its position." (Interv. Perm. Repr. C, Jan. 2002). Early contacts take place between an agent specially charged by the Presidency, the president of the working group, the secretary general of the dorsale and the Parliament's rapporteur. "We are aware of the opinion of the rapporteur/ the shadow rapporteur. We have an idea of what could be their position and we try to take this already into account.”(Interv. Perm Repr. C, Jan. 2001).

The role of COREPER vis-à-vis ministers and working groups has changed, too. "...Things come earlier up to COREPER than they would traditionally come. ...It used to be two weeks before Council met for the first time to come to an agreement. Now ... if the Presidency thinks that there is a possibility to come to an early agreement, they are coming quite early up with the subjects" (Interv. Perm. Repr. C, Jan. 2001). Under the leadership of the Presidency, the conciliation secretariat of the Council prepares a package document for COREPER which summarizes the discussion in the working group and contains new proposals (Interv. Council Secretariat 
A, Nov.2001). If a first reading agreement is not concluded - (interestingly an important impact of the possibility of early agreements has been to make the conclusions at second reading much more likely) - then "almost everything is done by COREPER." (Interv. Perm .Repr. C, Jan. 2002) It negotiates with the Parliament to come to an agreement on EP amendments in second reading. "Here the working group is completely out...It tends to say 'no' to everything and to want to stick to the common position... So everything comes up at COREPER level. COREPER takes more and more time. It becomes a negotiating machine where you give the Presidency a mandate to try to come to an agreement in second lecture...Everything switches over to COREPER”. (Interv. Perm. Repr. C, Jan. 2001).

One consequence of this shift is that "ministers are less and less important" (Interv. Perm. Repr. C, January 2001). In order to reach agreement with Parliament things are kept provisional much longer: "...if you negotiate with the Parliament you cannot go too early with a position to the Council of Ministers. Because ministers say: 'We cannot agree to this, we cannot agree to that'. So everything is done early on between COREPER and the Parliament" (Interv. Perm. Repr. C, Jan. 2001).

However, even while COREPER's position is enhanced vis-à-vis collective member state decision making at the political level, it may sometimes find itself sidelined by the Presidency. "There is always the risk that the Presidency runs its own race and then just presents the deed when it is finished" (Interv. Perm. Repr. A, Sept. 2001). While any agreement emerging from negotiations between the Council and the Parliament should be discussed formally at the COREPER level before further action is taken, this does not happen in all cases (Interv. Perm. Repr. A, September 2001). When the Presidency goes too far ahead of its fellow member states in reaching an agreement with the Parliament, it runs the risk of losing the confidence of its peers (Interv. Perm. Repr. A, Sept. 2001).

Finally, these new procedures also tend to weaken the control of national level actors in the member states - most particularly parliaments - over the European level of decision making. First reading solutions " .... are difficult to be fit in with procedures in some member states where national parliaments have to OK everything, because the point of decision-making has been moved from the Council and is made much earlier in the process" (Interv. Perm. Repr. A, Sept. 2001).

While the possibility to come to early agreements has clearly strengthened the Presidency and COREPER, codecision at the same time has opened up new perspectives for individual member states which have started to establish links with influential figures in Parliament. A specific member state that does not hold the Presidency, may have strong reservations about the likely common position of the Council - and may influence MEPs to vote against it. Particularly, if this member state holds a substantial number of MEPs, it may use its informal contacts with them to achieve outcomes which they would have difficulty in achieving in the Council alone or - when they would most likely be outvoted within the Council itself, or would find it embarrassing to openly defend a specific national interest (Parliament doing the "dirty work" on behalf of some 
Council members). As described by one MEP, "in a very important issue (MEPs) would mostly be advised by the governments what way they wish it to go...and they very often comply" (Interv. Rapporteur B, Jan. 2001) Thus, in the Takeover Directive vote in Parliament in 2001, the Spanish Conservative delegation at the last moment changed its opinion because of a phone call from the Spanish minister of economic affairs: "We expect our MEPs to support the Spanish position" (Interv. Rapporteur B, Jan. 2002) "It's very obvious that there are alliances between member states and the Parliament, and this has implications for how the democratic process might be hijacked...." (Interv. Perm. Repr. A, Sept. 2001); “The large member states, such as the British, try to influence their delegates" (Interv. Perm. Repr. Jan. 2001). This practice is especially tempting to those member states with many MEPs, such as Germany, as most notably seen in the debacle over the Takeovers Directive (where Germany - after conciliation - declined the compromise). Accordingly, larger member states may use the role of Parliament in the codecision process as a means of taking a "second bite at the cherry", often to the disadvantage of smaller states in the EU which do not command the same large numbers of MEPs and are worried at the implications of this possibility for future controversial issues and that the Council principle of solidarity be jeopardized.

In sum, the agents gaining power from increased interdependence are the rapporteurs and the coordinators of the large political groups, and policy experts in the Parliament, the Presidency and COREPER in the Council; the losers are the MEPs of the smaller political groups and the committee chairmen in the Parliament, and the sectoral ministers in the Council. What emerges empirically too, is that on the one hand in the Council, with its well structured and centralized set of procedures, the Presidency and COREPER gain in latitude vis-à-vis the national governments indicating a further centralization in the Council. However, on the other hand. it is also becoming easier for individual member states to evade Council solidarity and the Presidency leadership through establishing direct relationships with Parliament. In the Parliament, in contrast, even those actors with formal negotiating authority are to some extent dependent on those actors with informal power, e.g. coordinators and policy experts. The decentralized nature of decision making within Parliament means that it is often necessary to rely on these latter actors in order to create support for a compromise with Council in committee and plenary.

Our second hypothesis - specifying the first - addresses the most important basis of power of a mediating agent and its impact: the control of information flows.

When interdependence between arena $A$ and $B$ increases, then, ceteris paribus, actors in arena with privileged access to information about deliberation in another will have increased power to affect legislative outcomes.

There is some evidence in our interview data that indeed some mediating actors are using the information gained from their bargaining activities with the other body to influence the debate within their own organization. The Presidency may use its privileged position as a broker of information between Parliament and the other member states in the Council in order to extract concessions from the latter, claiming that these changes are necessary to win Parliament's ap- 
proval or to make concessions to the Parliament. "We are constantly told, 'the Parliament does not want this, the Parliament does not want that" (Interv. Perm. Repr. C, January 2001).

Pressure may be all the stronger because of the relative speed of negotiations, especially in the case of early agreement negotiations. Thus it is often difficult for COREPER officials to receive and assess information from the Presidency about the state of negotiations, inform their superiors in the member states, inform their national parliaments, receive responses, and convey them back to the Presidency, in the tight window of opportunity that is available.

Actors within the Parliament with privileged access may seek to enhance their leverage vis-à-vis their parliamentary colleagues through selectively providing information on Council's preferences. The rapporteur commands a mass of information from which she has to select in what to pass on to the committee chairpersons (Interv. Rapporteur B, Jan. 2002); "Il faut qu'il (le rapporteur) fait circuler énormément d'informations pertinentes à ses collègues "11 (Interv. Perm. Repr. B, Jan. 2002). While this power to withhold information is limited - there are other channels of information between Council and Parliament - it has proved a sore point in the relationship between rapporteurs and their committees.

Our third hypothesis addressed the direction of interdependence and resulting power of mediating agents:

The more arena $A$ depends on arena $B$, the less agents from arena $A$ can influence actors of arena $B$.

There is some empirical evidence that Council is becoming more dependent on the Parliament than the other way round in negotiating early agreement dossiers, especially those with deadlines attached. We have argued in previous work that the direction of dependence is determined by the formal position of a negotiating party, its vulnerability vis à vis negotiation failure, its time horizon and its resources, and shown how these factors often tend to militate in favor of the Parliament in specific items of legislation, and consequently in the informal institutions governing Council-Parliament relations (Farrell and Héritier 2002). As can be shown empirically the Parliament makes use of its strategic position, in particular the time pressure which the Council puts itself under. Thus, in one legislative area prioritised at Lisbon: "The fact that this particular piece of legislation had a deadline attached to it in the Lisbon conclusions was unbelievably important because it meant that the Council was desperate to meet its own deadline..." (Interv. Rapporteur A Nov. 2001). As the rapporteur for the dossier put it: "Look, I don't care. We [the Parliament] can sit on this for two years, but you are the guys, who at the intergovernmental level, have said you want this done by [a given date]. So the only way we're going to reach that deadline is through 'pre-conciliation”" (Interv. Rapporteur A, Nov. 2001).

The degree of dependence of the Council from the Parliament is also reflected in the extent to which the Council is willing to accept Parliament's procedural demands on a particular substan-

11 "The rapporteur must circulate enormous amounts of relevant information to his colleagues." (own translation) 
tive dossier, even when these demands may have longer term implications for the relative position in the decision-making process of the two bodies. An example of pressing for procedural concessions when the Council and the Commission are pressed for time is the International Accounting Standards proposal. As part of the Lamfalussy package for a reform of financial services, defined as urgent by the European Council, the Parliament linked a substantive question with the question for a right of call-back regarding comitology (Bergström 2002) decisions ("It is very easy...If we don't get it ((the right of call back)) there will be no legislation" - Interv. Rapporteur B, Jan. 2001), and succeeded in creating a precedent for longer term ParliamentCommission relations.

\subsubsection{Procedural responses to shifts in power}

The empirical changes that we describe in the previous section may have substantial implications for the balance of power within Council and Parliament (and we have shown earlier between Council and Parliament). To this development both bodies have responded with the proposal or realization of new institutional rules regarding intraorganizational and interorganizational decision-making processes.

How are actors in Parliament and Council who are worried about these developments (and their consequent loss of power) likely to respond? As we have suggested in our fourth hypothesis:

Actors who lose power through an increase in interdependence will seek to regain it through institutional change in a second stage of institutional development.

This institutional change will involve

- efforts to redefine the terms and the direction of interdependence,

- or the access of actors to negotiating authority and/or privileged information under interdependence.

And further we suggested in our fifth hypothesis:

Where negotiating authority and/or access to information are relatively evenly spread, or rotated, it will be relatively easy for actors to agree on institutional solutions.

And correspondingly, where negotiating authority and/or access to information are unevenly distributed, and are not rotated, institutional change will be conflictual and difficult to bring through.

To what extent can efforts be observed to curb the power of actors who have gained new advantages through informal negotiations? On the side of the Parliament there is considerable empirical evidence testifying to the discontent of those actors sidelined by the new practices (see above): "There was one point where the committee got very, very upset because they felt I had been negotiating things without clearing them with the committee... And that won't happen again, because people have woken up to the problem of allowing a rapporteur to negotiate what 
are in effect first and second reading amendments on behalf of the whole Parliament" (Interv. Rapporteur, EP, Sept. 2001).

Much of this has been phrased in terms of the Parliament becoming more like the Council - losing its democratic legitimacy as it becomes embroiled in non-transparent and non-accountable informal negotiations and deals behind closed doors (Shackleton 2001). As described by a sympathetic observer in a member state delegation, “...les parlementaires ont le sentiment d'être privés d'une tribune démocratique...Ils doivent retourner à leur constituants et doivent pouvoir leur dire: 'J'ai voté ceci, j'ai voté cela. Un amendement sous les 'early agreements' n'est plus lié au nom d'un parlementaire. C'est le rapport du rapporteur qui doit être adopté. Donc il n'y a plus cette visibilité politique des parlementaires pour les constituants" ${ }^{12}$ (Interv. Perm. Repr. B, Jan. 2002). Recent discussions have also seen the Vice-Presidents, coming together with committee chairmen to express objections to the new forms of informal cooperation and criticizing the lack of openness (Interv. Council Secr. October 2001).

What intra and interorganizational institutional reforms are proposed to meet these criticisms? The Vice Presidents call for a more transparent and accountable approach to negotiations on early agreement dossiers. In the EP Activity Report of Sept. 2001 they demanded drastic change in intra- and interorganizational negotiations: each negotiator should first get a formal mandate to engage in such bargaining by the committee in charge of an legislative item. The main "winners" of the new informal set of procedures, the rapporteurs, recognize the need for change, but argue against an overly formal approach, which they believe will make it more difficult to reach consensus (Interv. Rapporteur A, Oct. 2001). In the words of on: "The rapporteur should be free, with the shadow rapporteurs, to negotiate informally as much as possible with the Council, and not get bogged down in having formal scheduled meetings with some kind of preconciliation committee .... If you do that, the bureaucracies, the administrations of both the Parliament and the Council will get hold of this process and it will get gummed and glued up. But the rapporteur obviously needs to report back regularly to the committee and, obviously, can only make commitments on behalf of the committee or the Parliament with a caveat which says that this all depends on the final vote of first the committee and then the plenary" (Interv. Rapporteur Nov. 2001).

While a more centralized parliamentary system for the provision of information about discussions under codecision - as favoured for instance by the Commission ${ }^{13}$ - would create more transparency, it would be less flexible and unappealing to another set of actors who are losing out under the current system, the committee chairmen. For these powerful committee chairpersons a strengthening of the General Secretariat to improve information flows might have nega-

12 "The parliamentarians feel deprived of a democratic arena... They have to be able to go back to their constituents and say: 'I voted for this, I voted for that'. The amendments under an early agreement are not linked to the name of a parliamentarian. It is the report of the rapporteur which has to be adopted. Therefore, you don't have this political visibility of parliamentarians any longer." (own translation)

13 The Commission would have a better overview over on-going informal trialogues if a central information coordination would be installed. Under the current practice the Commission complains that it often learns about informal trialogues at very short notice. It feels sidelined. (Interv. Commission, Sept. 2001) 
tive implications for their autonomy more generally. Thus, the Parliament has found it very difficult to introduce effective reforms.

In contrast, intraorganizational reform in the Council has been much more consensual. To be true, the Council, in general is in favour of the new informal cooperative institutions and seeks to overcome the bottleneck in legislative work through a further multiplication and intensification of trialogues and technical meetings. (Report Council on Codecision, Nov. 2000:8). But as a response to some internal criticisms it has taken several institutional reform measures on a consensual basis. Thus it has instituted new intraorganizational rules as a consequence of the new practices, in particular to pacify national parliaments and governments who protest that they are not sufficiently informed. The solution has involved the centralized provision of information on the current state of play in specific negotiations. While the Parliament has a specialized staff in the Secretariat to service conciliations, the Council has created a "dorsale" which not only handles conciliation, but also the first and second reading, with officials attending the various committee meetings and drawing up reports. This means that 'delegations can inform their government and their national parliament accordingly, all along the procedure, and it doesn't come as a surprise at the end when we have a package." (Interview Perm. Repr. A, October 2001). This service is specifically intended to address the possibility that the Presidency may overstep the consensus among the member states, and to ensure that member states are informed sufficiently as to the specifics of the negotiation process. Beyond that the enhanced power of the Presidency has not given rise to demands for institutional reform because the presidency rotates among member states. If the proposals of some member states for a Presidency with a much longer term are accepted, one may predict with a high degree of confidence that this Presidency will be much more constrained than the current one; the risks and opportunities of opportunism will no longer be cross-cutting.

A second way of responding to the intra-organizational power shifts triggered by informal cooperation has been to seek to change the basis of inter-organizational cooperation. This is more attractive to figures who have lost out in Parliament insofar as it involves both the regularization of relations through the traditional Parliamentary committee process, and an increase in Parliament's overall influence, that is the direction of interdependence. Those in Parliament who are concerned about the weakening of committees and plenary call for a standardization of the informal process as to the parties involved and the procedure used, such as the establishing of a systematic link to the parliamentary committee (EC Activity Report Sept. 2001). They propose that Council should come to committee as the main mechanism of dialogue.. In its last activity report the Parliament even goes as far as to seek to make Parliamentary participation in informal trialogues conditional on Council representatives having first been present at committee meetings (EP Activity Report 2000/2001:24/25). However, it may be difficult for Parliament collectively to carry through on its threat - those MEPs who have increased influence under current arrangements are reluctant to give it up. In one prominent MEP's words: “They can write down whatever they want. They write a lot of reports. Nobody will take notice of that...Those people who are really doing the job, need the contacts and they use the contacts...I am an independent 
MEP. I am not one that follows the orders of the Vice President...There are some people who want such rules, but they have no chance"(Interv. Rapporteur B, Jan. 2002). As of yet, there is no evidence of the threat having been implemented. "There are still informal trialogues." (Interv. Perm. Repr. C, Jan. 2002).

The Council, for its part, is very reluctant to accept the invitation to "come to committee" , in part because of lack of time, but more importantly because COREPER hesitates to reveal member states' positions in the bargaining process in a public forum, arguing that it contradicts the spirit of solidarity of the Council (Interview EP, March 2001). As one member of the Council argues: "We have an old tradition in the Council that the Presidency does not reveal the individual position of a national delegation...It's fine to explain what the position of the Council is as long as you don't start pointing fingers at individual member states" (Interview Council Oct. 2001). Even if more and more frequently, Council representatives come to Parliament committee meetings, they emphasize that do not come to negotiate, only to present the common position (Interv. Conciliation Committee Jan. 2002) Symbolically however, it is also very important "que les représentants du Conseil se déplacent à Strasbourg ....Aller voir les parlementaires à Bruxelles quant ils sont en commissions, c'est bien, mais aller les voir à Strasbourg, c'est mieux...On leur signale : on se déplace pour vous'. ${ }^{14}$ (Interv. Perm. Repr. B, Jan. 2002). Vice versa, Council has refused MEP's requests to attend meetings of the Council working groups. "On ne peut pas dévoiler les différentes positions sur les amendements. On ne leur passe non plus les documents internes où c'est marqué 'réserve de l'Allemagne, réserve de la France 'etc. »" ${ }^{15}$ (Interv. Perm. Repr. B, Jan. 2002).

\section{Conclusion}

So what are the intraorganizational consequences of interorganizational cooperation and in particular of informal cooperation to achieve early agreements under codecision? In addressing this first question we argue that interdependence has asymmetric effects on power relations; some agents gain more in power than others within their own organizations to influence legislative outcomes. These are primarily the actors which have formal negotiating authority. Apart from these formally authorized mediating actors, however, it is agents with networking capacity and substantive political support as well as actors with policy expertise who gain clout in interorganizational bargaining. We find these expectations largely confirmed through the empirical evidence provided on the negotiations between the Council and the Parliament under the new codecision procedure. However, we also find that the gain in power of individual actors differs between the two organizations on account of the different institutional structures of the Council and the Parliament. The Council, in its working procedure, is rather centralized. Under these

14 that the Council representatives go to Strasbourg...To go and see the parliamentarians in Brussels when they meet in committees is good. But to go and see them in Strasbourg is better... You signal them: we came all this way to see you." (own translation)

15 "We cannot reveal the different (national) positions on amendments. Neither do we offer insight into internal documents where it is marked 'reservations of Germany, reservations of France etc.'” (own translation) 
conditions, the Presidency's power, is further enhanced, and COREPER's power is strengthened vis-à-vis ministers'power. By contrast, under conditions of decentralization, albeit fragmentation, as they exist in the Parliament, even actors with formal negotiating power, primarily the rapporteur, very much depend on the support and of actors commanding broad political support and networking capacity, in order to be successful with the negotiation result to be successful in committee and in plenary. Hence a general insight gained from our empirical exploration of the hypotheses which we put forward is that the intraorganizational consequences of interorganizational bargaining differ according to the prevailing institutional structure of an organization. In procedurally centralized organizations the top of the hierarchy tends to reinforced. In procedurally decentralized organizations the mutual dependency of formally authorized and informally powerful actors is enhanced. The enhancing of centralization process in the procedurally more hierarchical organization is not challenged because hierarchy is temporally limited. In our case because the Presidency rotates among member states in the Council.

Our second concern was the institutional responses to the power shifts caused by informal interorganizational cooperation. We argued that it is easier to right asymmetries of power if positional advantages are evenly, rather than unevenly distributed. We find that indeed, in the EP the losers (committee chairmen, small political groups) seek to claw back lost intraorganizational power. However, such institutional reforms are the subject of talk rather than implementation. Because the effects of these changes have been highly asymmetric, those actors which have done well from them have little reason to do more than pay lip service to the need for change. Further, the decentralized and fragmented structure of the Parliament means that it is difficult for actors who have been weakened by new developments successfully to bring through change. Actors within Parliament are relatively independent, because they are not subject to the disciplining function of having to support a government in power. It is thus more difficult to bring changes about. In the Council, by contrast, the centralization to the advantage of the Presidency is not challenged, because the "advantage" is equally distributed among all member states.

The Parliament, finding it difficult to reach internal consensus, has opted to seek external gains; effectively to increase its overall share of legislative competences. To the extent that this strategy does not impose asymmetric costs on actors (and where it does, there is resistance), it succeeds in generating support from all MEPs. The Parliament has been relatively successful in redefining interorganizational relations and the direction and degree of interdependence, so as to win ground vis-à-vis the Council. It has made some headway in forcing the Council "to come to committee" to defend its policy positions. In order to achieve procedural gains it has repeatedly sought to leverage the Council's need for the adoption of substantive measures into additional procedural long-term gains. 


\section{References}

Bergström, Carl F. (2002). The Development and Operation of Comitology. (European University Institute, Florence, Thesis Manuscript).

Bowler, Shaun, \& Farrell, David M. (1995) The Organizing of the European Parliament: Committees, Specialization and Coordination. British Journal of Political Science, 25, 219243.

Corbett, Richard. (2000). Academic Modeling of the Codecision Procedure: A Practioner's Puzzled Reaction. European Union Studies, 1, 73-81.

Crombez, Christophe. (1997). The Co-Decision Procedure in the European Union. Legislative Studies Quarterly, 22, 97-119.

Crozier, Michel, \& Friedberg, Erhard.(1977). L'acteur et le système. Paris: Le Seuil.

Evans, Peter, Jacobson, Harold, \& Putnam, Robert. (Eds.) (1993). Double-Edged Diplomacy: International Bargaining and Domestic Politics. Berkeley: University of California Press.

Evans, Peter. (1993).Building an Integrative Approach to International and Domestic Politics: Reflections and Projections. In Peter Evans, Harold Jacobson \& Robert Putnam (Eds.), Double-Edged Diplomacy: International Bargaining and Domestic Politics. (pp. 397430). Berkeley: University of California Press.

Farrell, Henry. (2002). Negotiating Privacy Across Arenas: The EU-US "Safe Harbor" Discussions. In Adrienne Héritier (Ed.), Common Goods: Reinventing European and International Governance. (pp. 105-127). Lanham, MD: Rowman and Littlefield.

Farrell, Henry, \& Héritier, Adrienne.(forthcoming). Formal and Informal Institutions under Codecision: Continuous Constitution-Building in Europe. Governance.

Farrell, Henry, \& Knight, Jack. (2002). Trust, Institutions and Institutional Evolution: Industrial Districts and the Social Capital Hypothesis. Mimeo.

Fligstein, Neil. (2001). Social Skill and the Theory of Fields. Mimeo.

Garrett, Geoffrey, \& Tsebelis, George. (2000). Legislative Politics in the European Union. European Union Politics, 1, 9-36.

Héritier, Adrienne. (2001). Market Integration and Social Cohesion: The Politics of Public Services in European Regulation. Journal of European Public Policy, 8, 825-852.

- (2002). Introduction. In Adrienne Héritier (Ed.), Common Goods: Reinventing European and International Governance. (pp. 1-27).Lanham, MD: Rowman and Littlefield. 
Hix, Simon. (2002). Constitutional Agenda-Setting through Discretion in Rule Interpretation: Why the European Parliament Won at Amsterdam. British Journal of Political Science, $32,259-280$.

Hooghe, Liesbet, \& Marks, Gary. (2001). Types of Multi-Level Governance. European Integration Online Papers, http://eiop.or.at/eiop/texte/2001-011a.htm.

Knight, Jack. (1992). Institutions and Social Conflict. Cambridge, UK: Cambridge University Press.

Lewis, Jeffrey. (2000). The methods of community in EU decision-making and administrative rivalry in the Council's infrastructure. Journal of European Public Policy, 7,2, 261-289.

Lord, Christopher. (1988). Democracy in the European Union. Sheffield: Sheffield Acadamic Press.

Majone, Giandomenico. (2001). Two Logics of Delegation: Agency and Fiduciary Relations in EU Governance. European Union Politics, 2,1, 103-122.

Marks, Gary, Hooghe, Liesbet, \& Blank, Kermit. (1996). European Integration from the 1980's: State-Centric V. Multi-Level Governance. Journal of Common Market Studies, 34, 341378.

Milner, Helen V. (1997). Interests, Institutions, and Information: Domestic Politics and International Relations. Princeton, NJ.: Princeton University Press.

Pierson, Paul. (2000). Increasing Returns, Path Dependence, and the Study of Politics. American Political Science Review, 94, 251-267.

Pollack, Mark. (1997). Delegation, Agency, and Agenda Setting in the European Community. International Organization, 51, 99-134.

Putnam, Robert D. (1988). Diplomacy and Domestic Politics: The Logic of Two-Level Games. International Organization, 42, 427-60.

Shackleton, Michael. (2000). The Politics of Codecision. Journal of Common Market Studies, $38,325-342$.

. (2001). Codecision since Amsterdam: A Laboratory for Institutional Innovation and Change. Paper presented at ECSA Seventh Biennial International Conference. 31 May 2 June 2001. Wisconsin, Madison.

Stacey, Jeffrey. (2001). Constitutional Re-engineering in the European Union: The Impact of Informal Interinstitutional Dynamics. Paper presented at ECSA Seventh Biennial International Conference. 31 May - 2 June 2001. Wisconsin, Madison. 
Sugden, Robert. (1986). The Economics of Rights, Co-operation and Welfare. Oxford: Basil Blackwell.

Tsebelis, George. (1990). Nested Games. Berkeley: University of California.

—. (2000). Veto Players and Institutional Analysis. Governance, 13, 441-474.

Wallace, Helen (forthcoming). The Council: An Institutional Chameleon? In a special issue of Governance, eds. Laura Cram and Alberta Sbragia.

\section{Documents}

EP Activities Report, May 1999:7/8

EP Activity Report, Sept. 2001

EP Activity Report 2000/2001:24/25

Report Council on Codecision, Nov. 2000:8

\section{Interviews}

Permanent Representation C, January 2001

Permanent Representation January 2001

Rapporteur B, January 2001

EP, March 2001

Rapporteur A, September 2001

Commission, September 2001

Permanent Representation A, September 2001

Rapporteur A, September 2001

MEP, September 2001

Rapporteur A, October 2001

Permanent Representation A, October 2001 
Council Official A, October2001

Council October 2001

Permanent Representation, October 2001

Council Secretariat October 2001

COREPER, October 2001

COREPER Official B, October 2001

COREPER official

Rapporteur November 2001

Council Secretariat official A, November 2001

Permanent Representation, January 2002

Rapporteur B, January 2002

Permanent Representation C, January 2002

Conciliation Committee, January 2002 